\title{
Molecular Genetics, Genomics and Biotechnology in Crop Plant Breeding, Series II
}

\author{
Søren K. Rasmussen
}

check for updates

Citation: Rasmussen, S.K. Molecular Genetics, Genomics and

Biotechnology in Crop Plant

Breeding, Series II. Agronomy 2021, 11 1577. https://doi.org/10.3390/ agronomy11081577

Received: 20 July 2021

Accepted: 2 August 2021

Published: 9 August 2021

Publisher's Note: MDPI stays neutral with regard to jurisdictional claims in published maps and institutional affiliations.

Copyright: (c) 2021 by the author Licensee MDPI, Basel, Switzerland This article is an open access article distributed under the terms and conditions of the Creative Commons Attribution (CC BY) license (https:// creativecommons.org/licenses/by/ $4.0 /)$
Department of Plant and Environmental Sciences, University of Copenhagen, Thorvaldsensvej 40, 1871 Frederiksberg C, Denmark; skr@plen.ku.dk

This second volume of this series of Special Issues provides research papers and reviews on the use of molecular marker technologies, genomics selection, site-directed mutagenesis, gene-discovery by genome-wide association studies and biotechnology in important grain crops, tubers, fruit bearing shrub and small fruit crops. Breeding crop plants for end-product use such as quality traits are greatly facilitated by the use of DNA molecular markers. Cost-efficient sequence technologies are available that allow markers to be developed even for orphan crops. Marker-assisted selection also facilitates the introgressive hybridisation of a new site-directed mutation developed in a pre-breeding line into elite cultivars. Other applications of molecular markers make it possible to monitor F1 hybrid seed production and the authenticity of plant-based products. The Nobel Prize in Chemistry 2020 was awarded to Emmanuelle Charpentier and Jennifer Doudna for the discovery of CRISPR-Cas9 scissors that facilitate site directed mutagenesis in all living organisms including the plant kingdom. In this Special Issue, the first paper presents the principles of this new mutation method [1] with instructive illustrations of the mechanism its uses in plants and the review presents recent developments of the methodology. The versatility of site-directed mutagenesis is shown by a survey of a diverse set of 11 crop plants and a wide range of quality traits, yield and disease targets demonstrate its versatility. There is a need for adaptation in soybean (Glycine max (L.) Merr.) for Sub-Sahara Africa to overcome yield-drag compared to the global average production and by using single nucleotide polymorphism (SNP) in a Tropical Glycine max germplasm interesting genetic material could be identified for future soybean breeding [2]. To support marker-assisted selection and cultivar identification in a germplasm of gooseberry (Ribes uva-cripa) with varying berry colours (green, yellow, red and black) the nucleotide sequence of eight genes involved in flavonoid biosynthesis were used to design simple sequence repeat (SSR) markers [3]. The colour of the edible part is also an important trait to breed for in cabbage (B. oleracea var. capitata f. alba) [4] and to support this trait, specific SNPs that are closely associated with anthocyanin accumulation at low temperature were identified. Resistance and susceptibility to pathogens is an important breeding target in red and black raspberry (Rubus L.) canes [5], where a waxy locus is controlling the epicuticular wax; SSR markers could be developed and used for breeding. A limitation of the use of SSR markers is that they were found to be difficult to transfer between the two subgenera raspberries. Saline soils cause problems in pomegranate (Punica granatum L.) production, where $\mathrm{Na} / \mathrm{H}$ antiporter genes have an important function in mitigating salt stress. SNP markers were designed by genome-wide analysis to discriminate between members of the gene family in pomegranate and their response to salinity [6]. The grain legume grasspea (Lathyrus satious L.) would require a significant breeding effort in order be revived as a protein legume for Italian husbandry and this study develops SSR markers that show their feasibility to support selection in a breeding nursery [7]. Marker trait associations (MTAs) for freezing tolerance in canola (Brassica napus L.) was carried out on a large and wide germplasm of winter-type canola [8]. Many MTAs were located in genes previously identified to be good candidate genes for freeze tolerance in plants. Molecular markers 
were used for sex determination in Beninese yam (Dioscorea rotundata Poir) [9]. The crop plant is grown for its tubers, which are an important stable food in Benin; however, very little breeding is going on in yam. In a study of maize (Zea mays L.) hybrids, SSR markers were found to be very useful in breeding due to their codominant nature, high number of alleles, easiness of automation and the ability to differentiate inbred lines, and three markers were identified to be particularly informative in relation to quantitative trait loci (QTL) [10]. A bibliographic survey for publications using modern molecular plant breeding methods such as QTL mapping, GWAS and genomic selection for the following key traits in crop improvement: abiotic stresses and nutrient limitations for the three most important grain crops, rice, wheat and maize, based on global production [11]. The review gives a comprehensive historic overview, such as which year these methods (QTL mapping, GWAS and genomic selection) were first published, and it includes 265 primary references. The current Special Issue II starts out with a review on site-directed mutagenesis in plant breeding and closes with a survey of the plant molecular biology used in the most important cereal crops worldwide. The CRISPR-Cas9 is dependent on the availability of nucleotide sequence and the functional analysis of the candidate gene. Furthermore, the use of the technology is not exempt from the genetic modification regulation in the European Union in the same way that induced mutagenesis is, but, fortunately, it can be used in research. Taken together, the two review papers that embrace this collection of original research will give students and breeders key references on the most recent and strongest method in molecular plant breeding, together with the use of molecular methods in the three main crops that feed the world.

The editor of this Special Issue is very thankful for the author's contribution of two review papers and nine research papers, demonstrating the wide applications of molecular tools in modern plant breeding.

Funding: Experimental work in the Molecular Plant Breeding Research Group of S.K.R. is supported by the Danish Agricultural Agency, Green Development and Demonstration Programme, grant number 34009-13-0659.

Conflicts of Interest: The author declares no conflict of interest.

\section{References}

1. Montecillo, J.; Chu, L.; Bae, H. CRISPR-Cas9 System for Plant Genome Editing: Current Approaches and Emerging Developments. Agronomy 2020, 10, 1033. [CrossRef]

2. Chander, S.; Garcia-Oliveira, A.; Gedil, M.; Shah, T.; Otusanya, G.; Asiedu, R.; Chigeza, G. Genetic Diversity and Population Structure of Soybean Lines Adapted to Sub-Saharan Africa Using Single Nucleotide Polymorphism (SNP) Markers. Agronomy 2021, 11, 604. [CrossRef]

3. Vidyagina, E.; Lebedev, V.; Subbotina, N.; Treschevskaya, E.; Lebedeva, T.; Shestibratov, K. The Development of the Genic SSR Markers for Analysis of Genetic Diversity in Gooseberry Cultivars. Agronomy 2021, 11, 1050. [CrossRef]

4. Song, H.; Park, J.; Hwang, B.; Yi, H.; Kim, H.; Hur, Y. SNP in DFR1 Coding Sequence Is Tightly Associated with Anthocyanin Accumulation in Cabbage (B. oleracea var. capitata f. alba) at Low Temperature. Agronomy 2020, 10, 602. [CrossRef]

5. Pinczinger, D.; Reth, M.; Keilwagen, J.; Berner, T.; Peil, A.; Flachowsky, H.; Emeriewen, O. Mapping of the Waxy Bloom Gene in 'Black Jewel' in a Parental Linkage Map of 'Black Jewel' $\times$ 'Glen Ample' (Rubus) Interspecific Population. Agronomy 2020, 10, 1579. [CrossRef]

6. Dong, J.; Liu, C.; Wang, Y.; Zhao, Y.; Ge, D.; Yuan, Z. Genome-Wide Identification of the NHX Gene Family in Punica granatum L. and Their Expressional Patterns under Salt Stress. Agronomy 2021, 11, 264. [CrossRef]

7. Aci, M.; Lupini, A.; Badagliacca, G.; Mauceri, A.; Lo Presti, E.; Preiti, G. Genetic Diversity among Lathyrus ssp. Based on Agronomic Traits and Molecular Markers. Agronomy 2020, 10, 1182. [CrossRef]

8. Chao, W.; Horvath, D.; Stamm, M.; Anderson, J. Genome-Wide Association Mapping of Freezing Tolerance Loci in Canola (Brassica napus L.). Agronomy 2021, 11, 233. [CrossRef]

9. Denadi, N.; Gandonou, C.; Missihoun, A.; Zoundjihékpon, J.; Quinet, M. Plant Sex Prediction Using Genetic Markers in Cultivated Yams (Dioscorea rotundata Poir.) in Benin. Agronomy 2020, 10, 1521. [CrossRef]

10. Bocianowski, J.; Nowosad, K.; Wróbel, B.; Szulc, P. Identification of Associations between SSR Markers and Quantitative Traits of Maize (Zea mays L.). Agronomy 2021, 11, 182. [CrossRef]

11. Benavente, E.; Giménez, E. Modern Approaches for the Genetic Improvement of Rice, Wheat and Maize for Abiotic ConstraintsRelated Traits: A Comparative Overview. Agronomy 2021, 11, 376. [CrossRef] 